\title{
Physiochemical Studies of Sodium Chloride on Mungbean (Vigna radiata L. Wilczek) and Its Possible Recovery with Spermine and Gibberellic Acid
}

\author{
Srijita Ghosh, Sanglap Mitra, and Atreyee Paul \\ Department of Botany, Scottish Church College, 1 and 3 Urquhart Square, Kolkata 700006, India \\ Correspondence should be addressed to Srijita Ghosh; srijita.ghosh910@gmail.com
}

Received 31 July 2014; Revised 24 October 2014; Accepted 31 October 2014

Academic Editor: Aryadeep Roychoudhury

Copyright (c) 2015 Srijita Ghosh et al. This is an open access article distributed under the Creative Commons Attribution License, which permits unrestricted use, distribution, and reproduction in any medium, provided the original work is properly cited.

\begin{abstract}
The physiological and biochemical responses to increasing $\mathrm{NaCl}$ concentrations, along with low concentrations of gibberellic acid or spermine, either alone or in their combination, were studied in mungbean seedlings. In the test seedlings, the root-shoot elongation, biomass production, and the chlorophyll content were significantly decreased with increasing $\mathrm{NaCl}$ concentrations. Salt toxicity severely affected activities of different antioxidant enzymes and oxidative stress markers. Activities of antioxidant enzymes, superoxide dismutase (SOD), and catalase (CAT) increased significantly over water control. Similarly, oxidative stress markers such as proline, malondialdehyde (MDA), and hydrogen peroxide $\left(\mathrm{H}_{2} \mathrm{O}_{2}\right)$ contents also increased as a result of progressive increase in salt stress. Combined application of $\mathrm{NaCl}$ along with low concentrations of either gibberellic acid $(5 \mu \mathrm{M})$ or spermine $(50 \mu \mathrm{M})$ in the test seedlings showed significant alterations, that is, drastic increase in seedling elongation, increased biomass production, increased chlorophyll content, and significant lowering in all the antioxidant enzyme activities as well as oxidative stress marker contents in comparison to salt treated test seedlings, leading to better growth and metabolism. Our study shows that low concentrations of either gibberellic acid or spermine will be able to overcome the toxic effects of $\mathrm{NaCl}$ stress in mungbean seedlings.
\end{abstract}

\section{Introduction}

Increase in the world population and the decreasing trend of arable land has led to a marked decrease in food security with abiotic stresses, salinity being one of the major contributors in decreasing the crop productivity. Nearly 800 million hectares of land all over the world ( $6 \%$ of the world's total land area) are salt affected [1]. Salinization problems are on the increase mainly due to poor irrigation drainage or agricultural practices [2]. This drastic increase in land area being affected by salinity urges the need to develop strategies to enhance crop productivity under saline conditions. The negative effects of salinity, owing to increase in $\mathrm{Na}^{+}$and $\mathrm{Cl}^{-}$ions (with $\mathrm{Cl}^{-}$ being more dangerous), disturb the homeostasis of essential nutrients [3-5], leading to both hyperionic and hyperosmotic stress. The effects may be membrane damage, nutrient imbalance, alterations in levels of growth regulators, enzymatic inhibition, reactive oxygen species (ROS) generation leading to DNA damage, and activation of programmed cell death [69]. Plants tend to develop multiple detoxification mechanisms to prevent ROS from damaging cellular components [10].

Phytohormones interact with nutrients synergistically or antagonistically and regulate plant growth and development under optimal and stressful environments. Different phytohormones such as cytokinins (CK) [11], auxins [12], gibberellins (GA) [13], ethylene [14], nitric oxide (NO) [15], jasmonates (JA) [16], and salicylic acid (SA) [17] play essential roles in alleviating salt stress by regulating plant growth and development. Gibberellic acid $\left(\mathrm{GA}_{3}\right)$ ameliorates harmful impacts of salinity $[13,18]$ by establishing better seedling growth and shoot-root biomass. $\mathrm{GA}_{3}$ favorably affects the water status of the seedlings by partially sustaining protein and RNA levels. Exogenous $\mathrm{GA}_{3}$ application increased length and dry mass and reduced oxidative stress marker proline in salt affected soybean plants. It also maintained normal growth and development and reversed the inhibitory effects of salt 
on germination and seedling development in Arabidopsis. $\mathrm{GA}_{3}$ induces salt tolerance in plants by increasing sucrose, reducing sugar contents, the protein synthesis machinery, and the activity of antioxidant enzymes [18-20].

Polyamines (PAs) are small, low molecular weight, nonproteinaceous, straight chain, aliphatic hydrocarbon compounds with amino and imino groups. They are positively charged, organic molecules that are ubiquitous in all living organisms. The three common PAs in plants are putrescine (Put), spermidine (Spd), and spermine (Spm), with some plants also having thermospermine (tSpm) in place of or in addition to Spm. They have been deemed important in preparing the plant for stress tolerance and to directly aid in ameliorating the causes of stress [21]. Exogenous polyamine application is said to increase endogenous PAs and reverse salt stress damage in vegetative tissues of several plants including rice [22-26]. Exogenous PA application also promotes reproductive development under normal growth conditions and offers protection to reproductive structures against abiotic stress [27]. Application of Put reduces the net accumulation of $\mathrm{Na}^{+}$and $\mathrm{Cl}^{-}$ions in different organs of Atropa belladonna subjected to salinity stress. Put increased the growth and the leaf tissue viability of salt treated rice cultivars $[22,27]$.

Pulses are the best dietary source of proteins and they play a very important role to fulfill the requirements of rapidly increasing population. Mungbean (Vigna radiata (L.) Wilczek) is an important, self-pollinated, environment friendly, short season pulse crop which is grown primarily for its protein rich edible seeds. Abiotic stresses severely reduce the productivity of almost all pulses, including mungbean [28]. However, stress-induced adverse effects are variable at various growth stages. In mungbean, the adverse effect on grain yield is more at the reproductive stage than that at other stages. Mungbean is known as a salt sensitive crop $[2,29]$ and increasing salt concentrations reduce seed germination, fresh and dry biomass, shoot and root lengths, photosynthesis, and yield attributes of mungbean $[2,5,28,30]$.

On this note, the present study is primarily focused to study the toxic effects of salt stress in mungbean and its possible amelioration by $\mathrm{GA}_{3}$ or $\mathrm{Spm}$ with emphasis on morphological parameters such as overall plant growth, fresh and dry weight, root, shoot, and leaf length, and certain biochemical changes including chlorophyll content, stress induced damage in the form of elevated malondialdehyde (MDA), proline, and hydrogen peroxide $\left(\mathrm{H}_{2} \mathrm{O}_{2}\right)$ content or the enhanced effect of antioxidant enzymes like catalase (CAT) and superoxide dismutase (SOD).

\section{Materials and Methods}

2.1. Plant Material, Growth Conditions, and Stress Treatments. Seeds of mungbean ( $V$. radiata L. Wilczek) variety B-105, obtained from Pulse and Oilseed Research Institute, Behrampore, were surface sterilized with $0.1 \%$ (w/v) $\mathrm{HgCl}_{2}$ for $10 \mathrm{~min}$, washed extensively, and allowed to germinate in Petri dishes lined with water-soaked filter paper at $27 \pm 2^{\circ} \mathrm{C}$ for two days. The germinated seedlings were next transferred to separate Petri dishes containing varying concentrations of $\mathrm{NaCl}(25 \mathrm{mM}, 50 \mathrm{mM}$, and $100 \mathrm{mM})$ with or without $5 \mu \mathrm{M}$ concentration of $\mathrm{GA}_{3}$ or $50 \mu \mathrm{M}$ Spm. Water controls $(0 \mathrm{mM} \mathrm{NaCl})$ were run parallel to each experiment. All the Petri dishes were maintained at well aerated places under properly illuminated conditions. Following eight days of stress imposition, $\mathrm{NaCl}$-stressed seedlings were monitored for their overall growth. In addition, the seedlings were washed thoroughly and used for the various biochemical analyses.

2.2. Measurement of Root Length and Shoot Length, Fresh Weight and Dry Weight of Seedlings. Following stress imposition of two-day-old germinated seedlings for eight days, about 20 seedlings were randomly selected from each set and washed thoroughly with water. The root, shoot, and leaf length were measured in centimeter scale in five independent experiments.

For calculation of fresh and dry weight, about 20 seedlings were selected for measuring the fresh weight of mungbean seedlings from each set separately. Following fresh weight measurement, the tissues were kept in hot air oven at $50^{\circ} \mathrm{C}$ for two days followed by three days at $80^{\circ} \mathrm{C}$ and the weight of dried seedlings was noted.

2.3. Estimation of Chlorophyll Content. About $0.5 \mathrm{~g}$ of leaf samples harvested from untreated or $\mathrm{NaCl}$-treated seedlings were used for the estimation of chlorophyll content [31]. Chlorophyll was extracted with $80 \%(\mathrm{v} / \mathrm{v})$ chilled alkaline acetone. The absorbance for chlorophyll $\mathrm{b}$ at $645 \mathrm{~nm}$ and for chlorophyll a at $663 \mathrm{~nm}$ and of total chlorophyll was recorded using the formula $[\{(20.2 \times A 645)+(8.02 \times A 663)\} / 1000 \times$ $W] \times V$, where " $W$ " is the fresh weight of the material and " $V$ " is the extraction volume and is expressed in terms of $\mu \mathrm{g} \mathrm{g}^{-1}$ fresh tissue.

2.4. Estimation of Proline Content. The proline content in the untreated or NaCl-treated seedlings was estimated [32]. $0.5 \mathrm{~g}$ of tissue was homogenized with $5 \mathrm{~mL}$ of $0.1 \mathrm{M}$ sulphosalicylic acid and centrifuged at $5000 \times \mathrm{g}$. The supernatant was adjusted to $5 \mathrm{~mL}$ with distilled water. $2 \mathrm{~mL}$ of the extract was incubated with $5 \mathrm{~mL}$ of glacial acetic acid and $5 \mathrm{~mL}$ of acid ninhydrin and the tubes were heated in boiling water bath for $1 \mathrm{~h}$. Following cooling of the tubes, the samples were extracted with $10 \mathrm{~mL}$ of toluene and the pink colour intensity was recorded at $520 \mathrm{~nm}$ against a standard curve prepared using known concentrations of proline and expressed in terms of $\mu \mathrm{gg}^{-1}$ fresh tissue.

2.5. Estimation of MDA. About $0.5 \mathrm{~g}$ of test seedlings was used for MDA assay [33]. The samples were homogenized with $50 \mathrm{mM}$ buffer solution, which contained $0.07 \%$ $\mathrm{NaH}_{2} \mathrm{PO}_{4} \cdot 2 \mathrm{H}_{2} \mathrm{O}$ and $1.6 \% \mathrm{Na}_{2} \mathrm{HPO}_{4} \cdot 12 \mathrm{H}_{2} \mathrm{O}$, and centrifuged at $20,000 \times \mathrm{g}$ for $25 \mathrm{~min}$ at $4^{\circ} \mathrm{C}$. About $4 \mathrm{~mL}$ of $20 \%(\mathrm{v} / \mathrm{v})$ trichloroacetic acid (TCA) containing $0.5 \%(\mathrm{w} / \mathrm{v})$ thiobarbituric acid was added to $1 \mathrm{~mL}$ aliquot of supernatant. The mixture was heated at $95^{\circ} \mathrm{C}$ for $30 \mathrm{~min}$, quickly cooled on ice, and centrifuged for $10 \mathrm{~min}$. The absorbance of the 
supernatant was read at $532 \mathrm{~nm}$ and the value of nonspecific absorption at $600 \mathrm{~nm}$ was subtracted from $532 \mathrm{~nm}$ reading. The MDA concentration was calculated using extinction coefficient $155 \mathrm{mM}^{-1} \mathrm{~cm}^{-1}$ and expressed in terms of $\mu \mathrm{Mg}^{-1}$ fresh tissue.

2.6. Estimation of $\mathrm{H}_{2} \mathrm{O}_{2}$ Content. The $\mathrm{H}_{2} \mathrm{O}_{2}$ content in the untreated or $\mathrm{NaCl}$-treated was estimated as described earlier [34]. $0.5 \mathrm{~g}$ of plant tissue was homogenized with cold $5 \%$ $(\mathrm{w} / \mathrm{v}) \mathrm{TCA}$ at $4^{\circ} \mathrm{C}$ and the homogenate was centrifuged at $17,000 \times \mathrm{g}$ at $4^{\circ} \mathrm{C}$ for $10 \mathrm{~min}$. The supernatant was immediately used for estimation of $\mathrm{H}_{2} \mathrm{O}_{2}$ by the ferrothiocyanate method. Each reaction mixture contained $2 \mathrm{~mL}$ of the extract, $0.5 \mathrm{~mL}$ of $50 \%$ TCA solution, $0.5 \mathrm{~mL}$ of $10 \mathrm{mM}$ ferrous ammonium sulfate, $0.3 \mathrm{~mL}$ of $2.5 \mathrm{M}$ potassium thiocyanate, and $1.7 \mathrm{~mL}$ of distilled water. The absorbance of the ferrothiocyanate complex formed was read at $480 \mathrm{~nm}$ and was compared with the standard curve prepared with known concentration of $\mathrm{H}_{2} \mathrm{O}_{2} \cdot \mathrm{H}_{2} \mathrm{O}_{2}$ content was expressed in terms of $\mu \mathrm{Mg}^{-1}$ fresh tissue.

2.7. Assay of Catalase Activity. The test seedlings were homogenized in $0.1 \mathrm{M}$ phosphate buffer $\mathrm{pH}$ 7.0. The homogenate was centrifuged at $10,000 \times \mathrm{g}$ for $20 \mathrm{~min}$ at $4^{\circ} \mathrm{C}$. The Catalase (CAT, EC 1.11.1.6) assay was performed following the standard protocol [35] with certain modifications. The standard reaction mixture contained $1 \mathrm{~mL}$ of enzyme extract, $10 \mathrm{~mL}$ of $0.1 \mathrm{M}$ phosphate buffer $\mathrm{pH} 7.4$, and $1 \mathrm{~mL}$ of $5 \% \mathrm{H}_{2} \mathrm{O}_{2}$ and the sets were incubated for $30 \mathrm{~min}$ at room temperature $\left(25^{\circ} \mathrm{C}\right)$. The blank set contained $1 \mathrm{~mL}$ of phosphate buffer instead of $1 \mathrm{~mL}$ of enzyme extract in a sample set. The reaction was stopped by the addition of $5 \mathrm{~mL}$ of $10 \% \mathrm{H}_{2} \mathrm{SO}_{4}$. The residual $\mathrm{H}_{2} \mathrm{O}_{2}$ was titrated against $0.02 \mathrm{~N} \mathrm{KMnO}_{4}$. By estimating the amount of $\mathrm{KMnO}_{4}$ consumed in terms of $\mathrm{H}_{2} \mathrm{O}_{2}(1 \mathrm{~mL}$ of $0.02 \mathrm{~N} \mathrm{KMnO}_{4} \sim 17 \mathrm{mg} \mathrm{H}_{2} \mathrm{O}_{2}$ ), total $\mathrm{H}_{2} \mathrm{O}_{2}$ was calculated. The total soluble protein content of the extract was also determined and the CAT activity was expressed in terms of $\mathrm{mg} \mathrm{H}_{2} \mathrm{O}_{2}$ decomposed $\mathrm{h}^{-1} \mathrm{mg}^{-1}$ total protein.

2.8. Assay of Superoxide Dismutase Activity. The test seedlings were homogenized in $50 \mathrm{mM}$ Tris- $\mathrm{HCl}$ buffer $\mathrm{pH} 7.5$ containing $0.1 \mathrm{mM}$ EDTA and $10 \%$ polyvinyl pyrrolidone. The homogenate was centrifuged at $10,000 \times \mathrm{g}$ for $20 \mathrm{~min}$ at $4^{\circ} \mathrm{C}$. The superoxide dismutase (SOD, EC 1.15.1.1) assay was performed following the standard protocol [36] with certain modifications. The standard reaction contained $2.5 \mathrm{~mL}$ $80 \mathrm{mM}$ Tris-HCl ( $\mathrm{pH}$ 8.9) containing $0.12 \mathrm{mM}$ EDTA and $10.8 \mathrm{mM}$ TEMED, $0.1 \mathrm{~mL}$ of $\left(3.3 \times 10^{-9}\right) \%$ BSA, $0.1 \mathrm{~mL} 6 \mathrm{mM}$ NBT, $0.1 \mathrm{~mL}$ of $0.6 \mathrm{mM}$ riboflavin in $5 \mathrm{mM} \mathrm{KOH}$, and $0.1 \mathrm{~mL}$ supernatant. The glass tubes containing the reaction mixtures were exposed to fluorescent light $(40 \mathrm{~W})$ at $25^{\circ} \mathrm{C}$. The reaction was terminated by turning the light off. The increase in absorbance due to formation of formazon was read at $560 \mathrm{~nm}$, and the enzyme activity was expressed as enzyme units (EU) $\mathrm{min}^{-1} \mathrm{mg}^{-1}$ total protein.
2.9. Protein Estimation. In all enzyme preparation protein estimation was done accordingly [37] using Bovine Serum Albumin (BSA, Sigma) as standard.

2.10. Statistical Analysis. The experiments were carried out in a completely randomized design with five replicates; each replicate comprised a single Petri dish, containing an average of 50 seeds. The data and significant differences among mean values were compared by descriptive statistics ( \pm standard error, SE) followed by Student's $t$-test.

\section{Results and Discussions}

3.1. Effect of $\mathrm{NaCl}$ Treatment on Seedling Growth and Development. Salt treatment showed marked decline in normal growth and development in mungbean seedlings. The extent of retardation enhanced drastically with the progressive increase in salt concentrations [2], the maximum inhibition being at the highest concentration, $100 \mathrm{mM} \mathrm{NaCl}$ (Figures 1(a) and 2(a)). Still higher concentrations were not tried as the seedlings failed to survive, showing brownish brittle roots, reddish shoots, and bleached leaves. The inhibitory effect was more pronounced in shoot than in root and leaves. The primary root length was decreased by about $15 \%, 37 \%$, and $52 \%$ in response to $25 \mathrm{mM}, 50 \mathrm{mM}$, and $100 \mathrm{mM} \mathrm{NaCl}$ concentrations. In contrast, the shoot lengths on treatment with $25 \mathrm{mM}, 50 \mathrm{mM}$, and $100 \mathrm{mM} \mathrm{NaCl}$ concentrations decreased by $15 \%, 31 \%$, and $68 \%$ and leaf lengths by $22 \%, 34 \%$, and $53 \%$, respectively. When test seedlings were treated jointly with either $5 \mu \mathrm{M} \mathrm{GA}_{3}$ (Figures 1 (b) and $2(\mathrm{~b})$ ) or $50 \mu \mathrm{M}$ Spm (Figures 1(c) and 2(b)), the inhibitory effect caused by salt treatment alone was partially relieved. Here $5 \mu \mathrm{M} \mathrm{GA}$ and $50 \mu \mathrm{M}$ Spm were standardized by the authors as amelioration dosage. On joint application of $100 \mathrm{mM} \mathrm{NaCl}$ with $5 \mu \mathrm{M} \mathrm{GA}_{3}$, the shoot length decreased by $14 \%$ over water control, while joint application of $100 \mathrm{mM} \mathrm{NaCl}$ with $50 \mu \mathrm{M}$ Spm showed an increase of $1 \%$ over water control. Higher concentrations of either $\mathrm{GA}_{3}$ or Spm led to increased oxidative damage in the test seedlings. Also $25 \mathrm{mM}$ and $50 \mathrm{mM} \mathrm{NaCl}$ treated test seedlings showed comparatively less damage in respect to water control and hence all further experiments were performed with $100 \mathrm{mM} \mathrm{NaCl}$ concentration.

The reduction in fresh weight (Figure 3 ) and dry weight (Figure 4) of seedlings with respect to control was evident with $\mathrm{NaCl}$ stress. The fresh weight of seedlings reduced by as much as $92 \%$ at $100 \mathrm{mM}$ concentrations over water control. The decrease in dry weight of seedlings was about $80 \%$ as compared to water control at the above mentioned $\mathrm{NaCl}$ concentrations. Joint application of either $5 \mu \mathrm{M} \mathrm{GA}_{3}$ or $50 \mu \mathrm{M}$ Spm significantly increased the fresh as well as dry weight of treated samples as compared to direct $\mathrm{NaCl}$ treatment. In case of joint application of $100 \mathrm{mM} \mathrm{NaCl}$ with $5 \mu \mathrm{M} \mathrm{GA}$, the fresh and dry weights were decreased by about $45 \%$ and $60 \%$ over water control, while in case of joint application of $100 \mathrm{mM} \mathrm{NaCl}$ with $50 \mu \mathrm{M}$ Spm, the fresh and dry weights were decreased by about $17 \%$ and $15 \%$ over water control.

Salinity is known to cause several deleterious morphological effects on different stages of plant growth and 


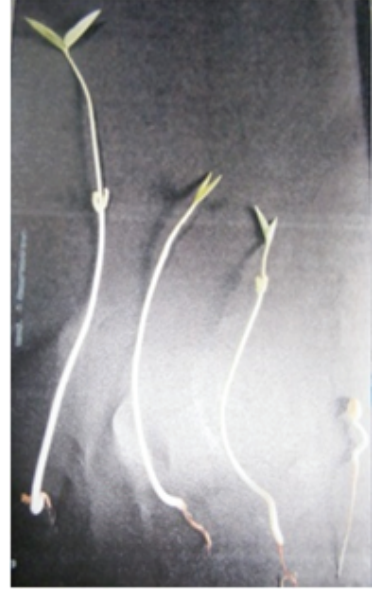

(a)

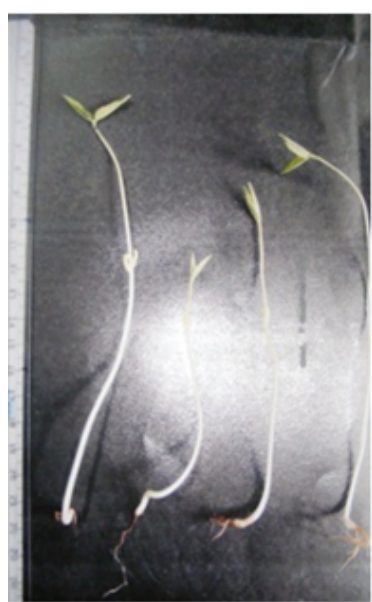

(b)

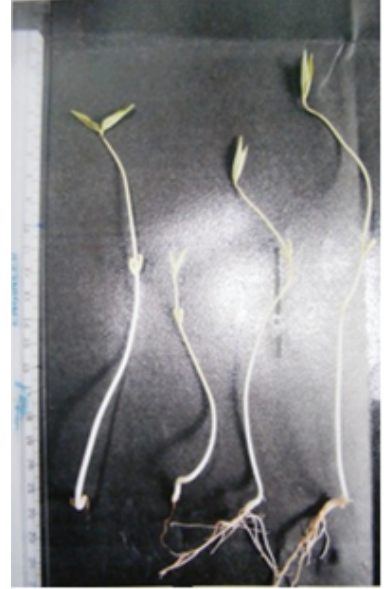

(c)

Figure 1: (a) Effect of $\mathrm{NaCl}$ on the growth of 10-day-old mungbean seedling. (b) Effect of $\mathrm{NaCl}$ on growth of 10-day-old mungbean seedling and its possible amelioration with $5 \mu \mathrm{M} \mathrm{GA}_{3}$. (c) Effect of $\mathrm{NaCl}$ on growth of 10-day-old mungbean seedling and its possible amelioration with $50 \mu \mathrm{M}$ Spm.

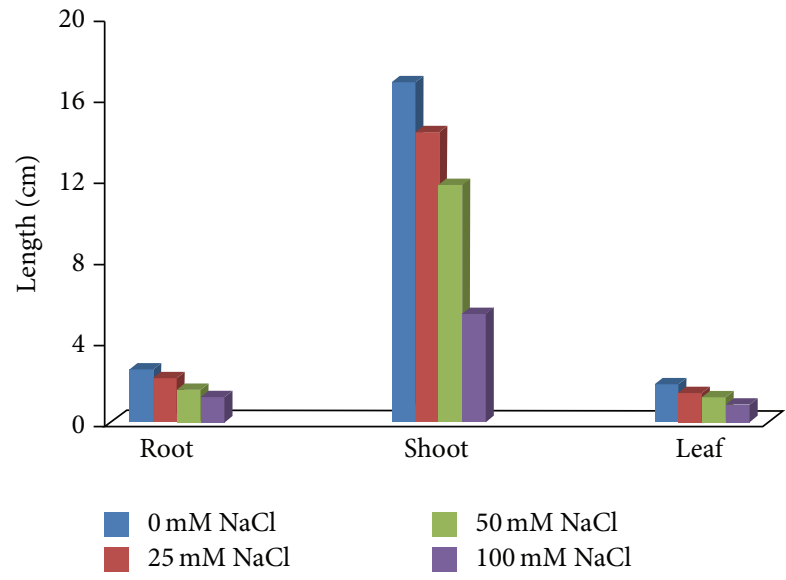

(a)

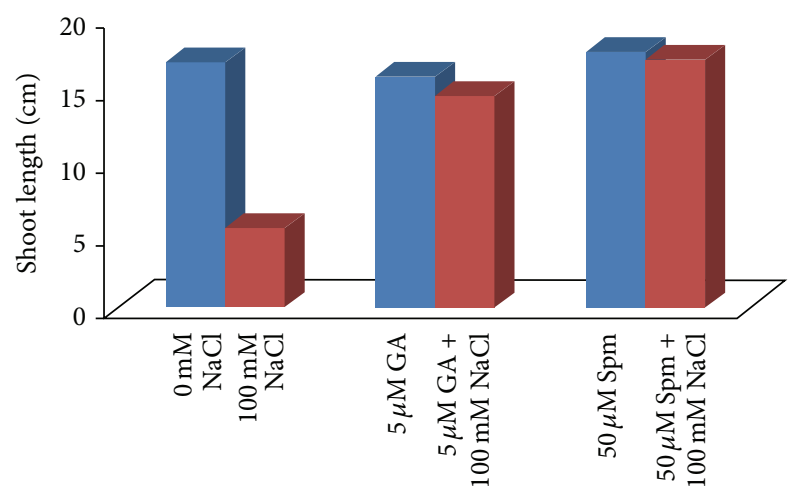

Salt concentration

(b)

FIGURE 2: (a) Effect of $\mathrm{NaCl}$ on the root, shoot, and leaf length of 10 day-old mungbean seedling. (b) Effect of $\mathrm{NaCl}$ on the shoot length of 10-day-old mungbean seedling and its possible amelioration with $5 \mu \mathrm{M} \mathrm{GA}_{3}$ and $50 \mu \mathrm{M} \mathrm{Spm}$.

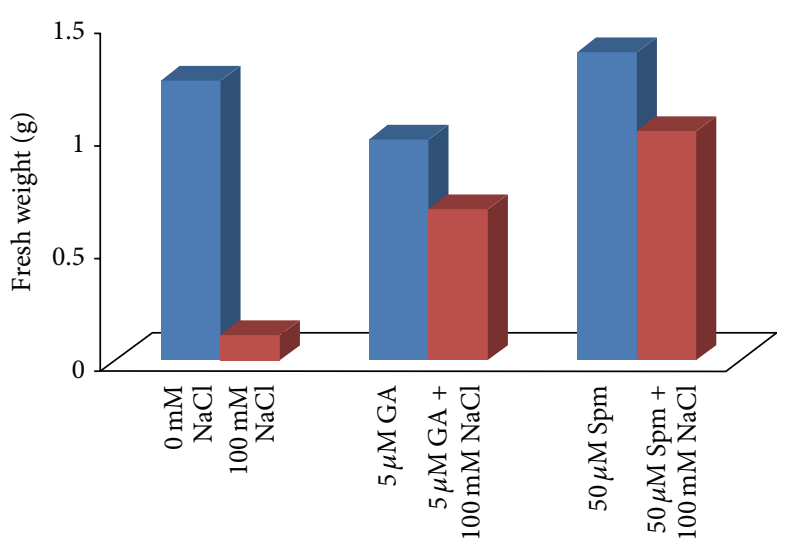

Salt concentrations

FIGURE 3: Effect of $\mathrm{NaCl}$ on the fresh weight of 10-day-old mungbean seedling and its possible amelioration with $5 \mu \mathrm{M} \mathrm{GA}$ and $50 \mu \mathrm{M}$ Spm.

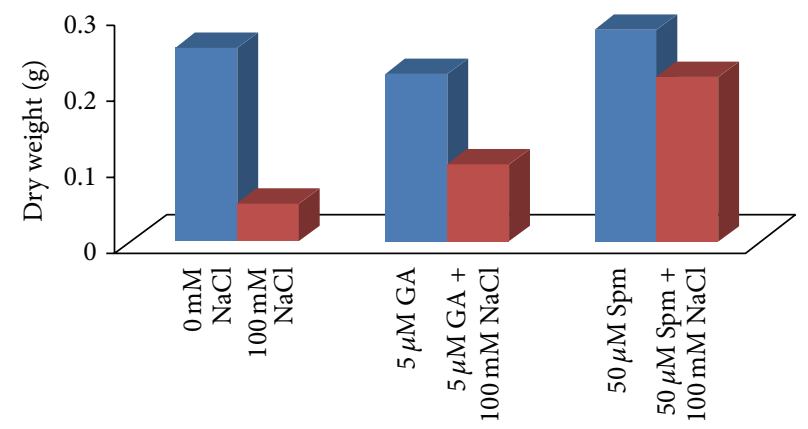

Salt concentration

FIGURE 4: Effect of $\mathrm{NaCl}$ on the dry weight of 10-day-old mungbean seedling and its possible amelioration with $5 \mu \mathrm{M} \mathrm{GA}$ and $50 \mu \mathrm{M}$ Spm. 


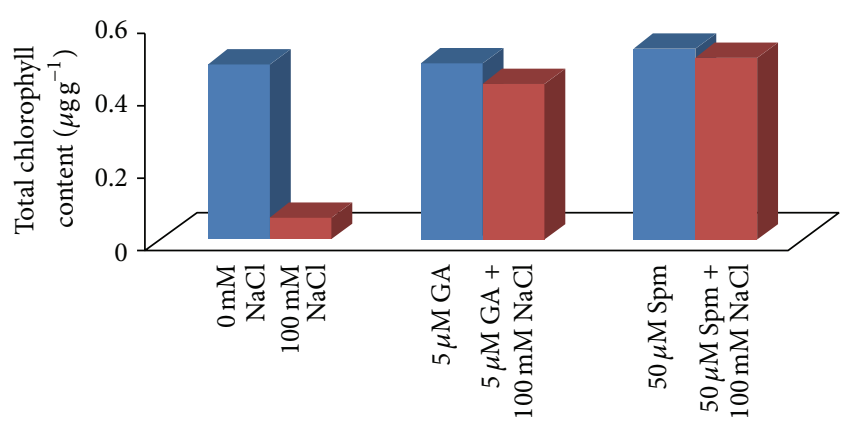

Salt concentration

Figure 5: Effect of $\mathrm{NaCl}$ on the total chlorophyll content of 10day-old mungbean seedling and its possible amelioration with $5 \mu \mathrm{M}$ $\mathrm{GA}_{3}$ and $50 \mu \mathrm{M} \mathrm{Spm}$.

development. Growth as well as metabolism is affected under salinity stress $[38,39]$. The salinity at seedling stage of cereals causes reduction in germination percentage, fresh and dry weight of shoot and roots [40]. The effects of salinity on plant growth are associated with low osmotic potential and nutrient imbalance. Reduced root and shoot growth in response to salt stress has already been reported in different plant species $[2,5]$. Our experiment showed that the root, shoot, and leaf length as well as fresh and dry weights of $\mathrm{NaCl}$-treated seedlings decreased with the increasing $\mathrm{NaCl}$ concentration over water control. Decrease in seedling vigour under salinity stress is due to the reduced ability of imbibitions resulting in limited hydrolysis of food reserves from storage tissues. Application of low concentrations of exogenous $\mathrm{GA}_{3}$ or Spm was able to reverse the deleterious effects of high salinity stress and allowed normal growth of the seedlings.

3.2. Effect of $\mathrm{NaCl}$ Treatment on Chlorophyll Content. It has already been reported that mungbean plants grown under salinity stress showed excess accumulation of leaf $\mathrm{Na}^{+}$ and $\mathrm{Cl}^{-}$resulting in excess reactive oxygen species (ROS) production, reduced photosynthesis, and plant growth [5]. In accordance with previously cited literature, there was a significant decrease in chlorophyll content in $100 \mathrm{mM} \mathrm{NaCl}$ treated test seedlings (Figure 5). With respect to water control, the reduction in chlorophyll content was about $89 \%$ at $100 \mathrm{mM} \mathrm{NaCl}$ concentrations. Joint application of $5 \mu \mathrm{M} \mathrm{GA}_{3}$ or $50 \mu \mathrm{M}$ Spm significantly increased the total chlorophyll content with respect to control. In case of joint application of $100 \mathrm{mM} \mathrm{NaCl}_{\text {with }} 5 \mu \mathrm{M} \mathrm{GA}_{3}$, the reduction in chlorophyll content was about $11 \%$ over water control while in case of joint application of $100 \mathrm{mM} \mathrm{NaCl}$ with $50 \mu \mathrm{M} \mathrm{Spm}$, the chlorophyll content was increased by about $3 \%$ over water control.

3.3. Effect of $\mathrm{NaCl}$ Treatment on the Oxidative Stress Markers. Proline, malondialdehyde (MDA), and hydrogen peroxide $\left(\mathrm{H}_{2} \mathrm{O}_{2}\right)$ contents are utilized as stress markers for oxidative damage and are generally affected by abiotic stress. Proline, an amino acid, acts as a cytoplasmic osmoticum and protects the protein against denaturation [36]. Under salinity stress, osmolyte such as proline maintains cellular homeostasis

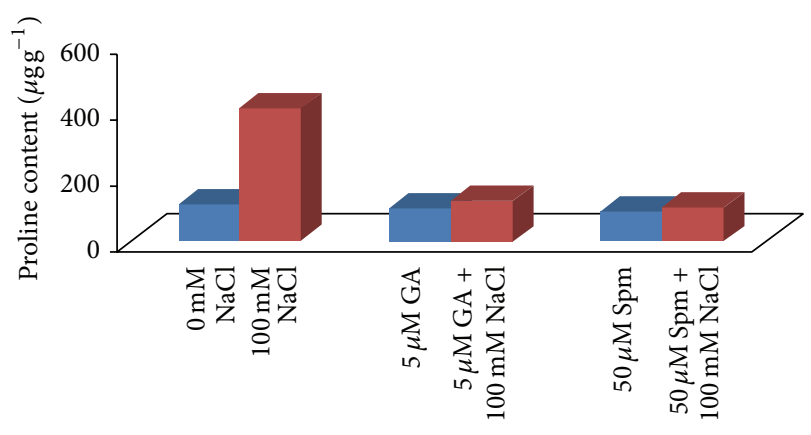

Salt concentration

FIGURE 6: Effect of $\mathrm{NaCl}$ on the total proline content of 10-day-old mungbean seedling and its possible amelioration with $5 \mu \mathrm{M} \mathrm{GA}$ and $50 \mu \mathrm{M} \mathrm{Spm}$.

through osmotic regulation and induces physiological processes favorably. In our experiment, application of $100 \mathrm{mM}$ $\mathrm{NaCl}$ concentration resulted in a drastic increase (3.6 times) in the proline content over water control. In case of joint application of $100 \mathrm{mM} \mathrm{NaCl}$ with $5 \mu \mathrm{M} \mathrm{GA}_{3}$, the increase in proline content was about 1.1 times over water control, while in case of joint application of $100 \mathrm{mM} \mathrm{NaCl}$ with $50 \mu \mathrm{M}$ Spm, the proline content was almost the same as water control (Figure 6). Malondialdehyde (MDA) which is often used as an indicator of oxidative damage is produced during peroxidation of membrane lipid by decomposition of polyunsaturated fatty acid. In our present study, we observed that MDA content was increased by about 2.5 times at $100 \mathrm{mM} \mathrm{NaCl}$ concentrations. In case of joint application of $100 \mathrm{mM} \mathrm{NaCl}$ with $5 \mu \mathrm{M} \mathrm{GA}$, the increase in MDA content was about 1.2 times over water control, while in case of joint application of $100 \mathrm{mM} \mathrm{NaCl}$ with $50 \mu \mathrm{M}$ Spm, the MDA content was increased by about 1.2 times over water control (Figure 7). It has been shown that during salt stress $\mathrm{H}_{2} \mathrm{O}_{2}$ serves as a signal molecule and plays a role in plant defense. Increased level of $\mathrm{H}_{2} \mathrm{O}_{2}$ causes membrane damage due to formation of ROS species. The $\mathrm{H}_{2} \mathrm{O}_{2}$ content was also increased by about 2.6 times at $100 \mathrm{mM} \mathrm{NaCl}$ concentration. In case of joint application of $100 \mathrm{mM} \mathrm{NaCl}$ with $5 \mu \mathrm{M} \mathrm{GA}$, the $\mathrm{H}_{2} \mathrm{O}_{2}$ content was almost the same as water control, while in case of joint application of $100 \mathrm{mM} \mathrm{NaCl}$ with $50 \mu \mathrm{M} \mathrm{Spm}$, the $\mathrm{H}_{2} \mathrm{O}_{2}$ content was increased by about 1.1 times over water control (Figure 8). During joint application of either $\mathrm{GA}_{3}$ or Spm in low concentration along with $\mathrm{NaCl}$ treatment, the inhibitory effect caused by salinity stress was significantly ameliorated over water control in accordance with previously cited literature [2].

3.4. Effect of $\mathrm{NaCl}$ Treatment on the Antioxidant Enzymes. Salt toxicity influences complex biochemical responses and several defensive mechanisms including production of enzymatic as well as nonenzymatic antioxidants, which detoxify ROS that rapidly occurs in plants due to increasing salt concentration. Increased activities of many of the antioxidant enzymes in plants combat oxidative stress induced by salinity stress [9] and various environmental stresses. Maintenance 


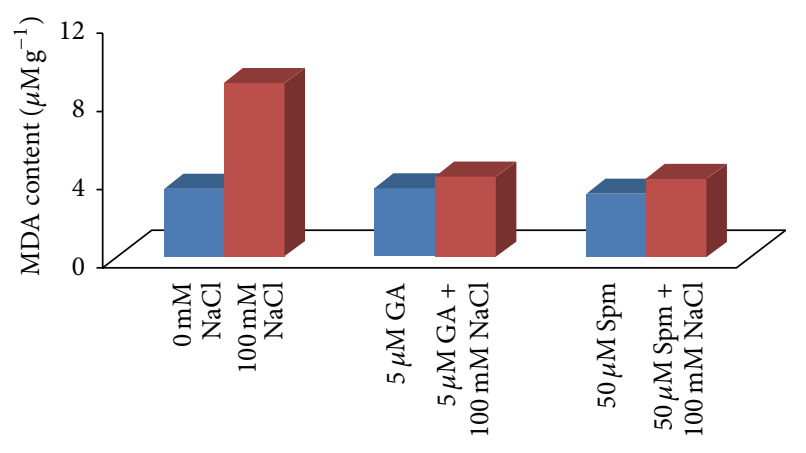

Salt concentration

Figure 7: Effect of $\mathrm{NaCl}$ on the MDA content of 10-day-old mungbean seedling and its possible amelioration with $5 \mu \mathrm{M} \mathrm{GA}$ and $50 \mu \mathrm{M}$ Spm.

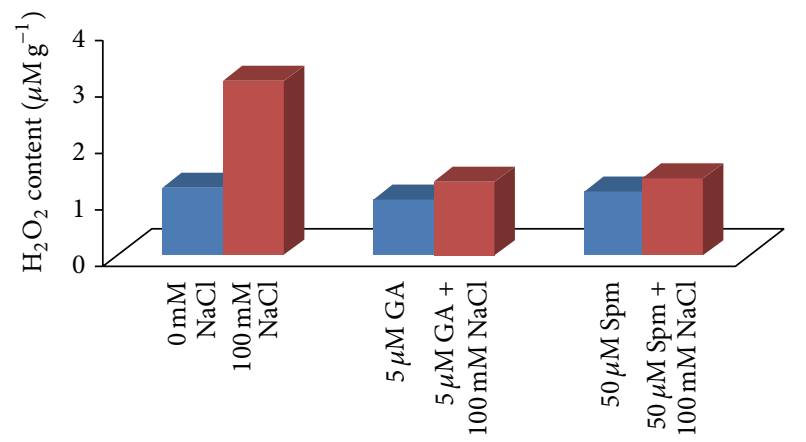

Salt concentration

Figure 8: Effect of $\mathrm{NaCl}$ on the $\mathrm{H}_{2} \mathrm{O}_{2}$ content of 10-day-old mungbean seedling and its possible amelioration with $5 \mu \mathrm{M} \mathrm{GA}$ and $50 \mu \mathrm{M} \mathrm{Spm}$.

of a high antioxidant capacity to scavenge the toxic ROS has been linked to increased tolerance of plants to these environmental stresses [41, 42]. SOD is a major superoxide scavenger and provides a first line of defense against cellular injury due to abiotic stress. The highly reactive superoxide is then converted to $\mathrm{H}_{2} \mathrm{O}_{2}$ by SOD. The excess $\mathrm{H}_{2} \mathrm{O}_{2}$, which itself is toxic for the plant, is then scavenged by CAT activity. CAT activity was expressed as the amount of $\mathrm{H}_{2} \mathrm{O}_{2}$ decomposed. In our experiment with increase in salinity stress, a significant enhancement in CAT activity (2.9 times) with respect to water control in the seedlings (Figure 9) was observed.

A similar trend was also observed after $\mathrm{NaCl}$ stress imposition, where the SOD activity in treated seedlings was drastically elevated (2.4 times) with respect to water control (Figure 10).

Joint application of either $\mathrm{GA}_{3}$ or Spm in low concentration along with $\mathrm{NaCl}$ in mungbean seedlings altered the activities of antioxidant enzymes in comparison to $100 \mathrm{mM}$ $\mathrm{NaCl}$ treatment alone. During joint application of $100 \mathrm{mM}$ $\mathrm{NaCl}$ with $5 \mu \mathrm{M} \mathrm{GA}_{3}$, the increment in CAT activity was about 1.2 times over water control, while in case of joint application of $100 \mathrm{mM} \mathrm{NaCl}$ with $50 \mu \mathrm{M}$ Spm, the CAT

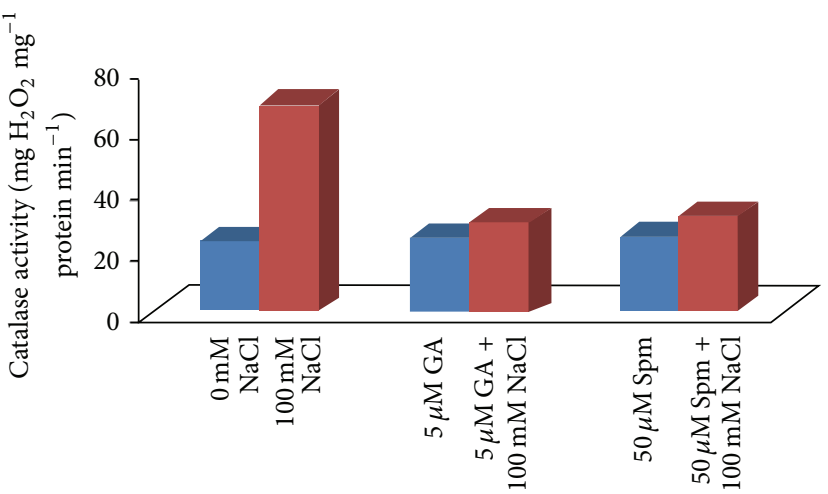

Salt concentration

FIGURE 9: Effect of $\mathrm{NaCl}$ on the catalase activity of 10-day-old mungbean seedling and its possible amelioration with $5 \mu \mathrm{M} \mathrm{GA}$ and $50 \mu \mathrm{M} \mathrm{Spm}$.

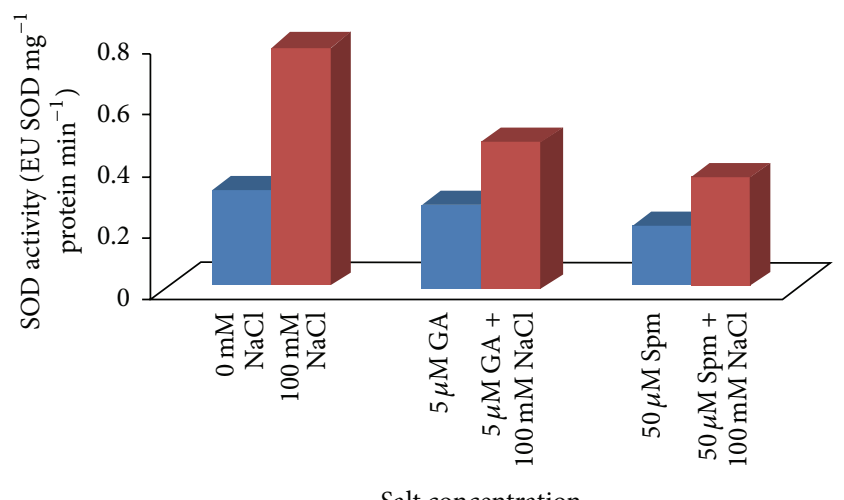

FIGURE 10: Effect of $\mathrm{NaCl}$ on the SOD activity of 10-day-old mungbean seedling and its possible amelioration with $5 \mu \mathrm{M} \mathrm{GA}$ and $50 \mu \mathrm{M}$ Spm.

activity was increased by about 1.3 times over water control (Figure 9). In case of joint application of $100 \mathrm{mM} \mathrm{NaCl}$ with $5 \mu \mathrm{M} \mathrm{GA}$, the increment in SOD activity was about 1.5 times over water control, while in case of joint application of $100 \mathrm{mM} \mathrm{NaCl}$ with $50 \mu \mathrm{M}$ Spm, the SOD activity was increased by about 1.1 times over water control (Figure 10).

\section{Conclusion}

From this present study, it can be concluded that the application of $\mathrm{NaCl}$ adversely affected the growth and defense mechanism as well as metabolism of mungbean seedlings. Salt tolerance is a complex phenomenon in plants, and various research methodologies and genetic approaches are used to characterize the diverse biochemical events that occur in response to salt stress. High concentrations of salt induce stunted growth and loss in chlorophyll content as well as oxidative damages by altering antioxidant machinery, leading to membrane damage through lipid peroxidation. Applications of low concentrations of phytohormones such as $\mathrm{GA}_{3}$ and $\mathrm{PAs}$ such as $\mathrm{Spm}$ in presence of $\mathrm{NaCl}$ in high 
concentrations play an antagonistic role in salt uptake. Thus, their use in low concentration in salt contaminated soil may help to grow mungbean plants with normal vigour, better yield and produce salt tolerant varieties.

\section{Conflict of Interests}

The authors declare that there is no conflict of interests regarding the publication of this paper.

\section{Acknowledgment}

The authors are thankful to Dr. Ashim Kumar Ghosh, ExAssociate Professor of Botany, City College, for his valuable suggestions.

\section{References}

[1] Food and Agricultural Organization (FAO), Land and Plant Nutrition Management Service, 2009, http://www.fao.org/wsfs/ forum2050/en/.

[2] P. Saha, P. Chatterjee, and A. K. Biswas, " $\mathrm{NaCl}$ pretreatment alleviates salt stress by enhancement of antioxidant defense system and osmolyte accumulation in mungbean (Vigna radiata 1. wilczek)," Indian Journal of Experimental Biology, vol. 48, no. 6, pp. 593-600, 2010.

[3] E. A. ghogdi, A. Izadi-Darbandi, and A. Borzouei, "Effects of salinity on some physiological traits in wheat (Triticum aestivum L.) cultivars," Indian Journal of Science and Technology, vol. 5, no. 1, pp. 1901-1906, 2012.

[4] N. K. Fageria, V. C. Baligar, and Y. C. Li, "The role of nutrient efficient plants in improving crop yields in the twenty first century," Journal of Plant Nutrition, vol. 31, no. 6, pp. 1121-1157, 2008.

[5] A. Roychoudhury and S. Ghosh, "Physiological and biochemical responses of mungbean (Vigna radiata L. Wilczek) to varying concentrations of cadmium chloride or sodium chloride," Unique Journal of Pharmaceutical and Biological Sciences, vol. 1, no. 3, pp. 11-21, 2013.

[6] M. Hasanuzzaman, M. A. Hossain, J. A. T. da Silva, and M. Fujita, "Plant responses and tolerance to abiotic oxidative stress: antioxidant defenses is a key factors," in Crop Stress and Its Management: Perspectives and Strategies, V. Bandi, A. K. Shanker, C. Shanker, and M. Mandapaka, Eds., pp. 261-316, Springer, Berlin, Germany, 2012.

[7] S. S. Gill and N. Tuteja, "Polyamines and abiotic stress tolerance in plants," Plant Signaling \& Behavior, vol. 5, no. 1, pp. 26-33, 2010.

[8] P. Sharma, A. B. Jha, R. S. Dubey, and M. Pessarakli, "Oxidative stress and antioxidative defense system in plants growing under abiotic stresses," in Handbook of Plant and Crop Stress, M. Pessarakli, Ed., pp. 89-138, Taylor \& Francis, Boca Raton, Fla, USA, 3rd edition, 2010.

[9] P. Sharma, A. B. Jha, R. S. Dubey, and M. Pessarakli, "Reactive oxygen species, oxidative damage, and antioxidative defense mechanism in plants under stressful conditions," Journal of Botany, vol. 2012, Article ID 217037, 26 pages, 2012.

[10] S. Turan and B. C. Tripathy, "Salt and genotype impact on antioxidative enzymes and lipid peroxidation in two rice cultivars during de-etiolation," Protoplasma, vol. 250, no. 1, pp. 209222, 2013.
[11] X. Wu, J. He, J. Chen, S. Yang, and D. Zha, "Alleviation of exogenous 6-benzyladenine on two genotypes of eggplant (Solanum melongena Mill.) growth under salt stress," Protoplasma, vol. 251, no. 1, pp. 169-176, 2014.

[12] M. Fatma, M. I. R. Khan, A. Masood, and N. A. Khan, "Coordinate changes in assim-ilatory sulphate reduction are correlated to salt tolerance: involvement of phytohormones," Annual Review \& Research in Biology, vol. 3, no. 3, pp. 267-295, 2013.

[13] N. Iqbal, R. Nazar, M. I. R. Khan, A. Masood, and N. A. Khan, "Role of gibberellins in regulation of source sink relations under optimal and limiting environmental conditions," Current Science, vol. 100, no. 7, pp. 998-1007, 2011.

[14] N. Iqbal, A. Masood, and N. A. Khan, "Phytohormones in salinity tolerance: ethylene and gibberellins cross talk," in Phytohormones and Abiotic Stress Tolerance in Plants, N. Khan, N. Nazar, R. Iqbal, and N. A. Anjum, Eds., Springer, Berlin, Germany, 2013.

[15] A. Uchida, A. T. Jagendorf, T. Hibino, T. Takabe, and T. Takabe, "Effects of hydrogen peroxide and nitric oxide on both salt and heat stress tolerance in rice," Plant Science, vol. 163, no. 3, pp. 515-523, 2002.

[16] M. I. R. Khan and N. A. Khan, "Salicylic acid and jasmonates: approaches in abiotic stress tolerance," Journal of Plant Biochemistry \& Physiology, vol. 1, no. 4, article e113, 2013.

[17] R. Nazar, N. Iqbal, S. Syeed, and N. A. Khan, "Salicylic acid alleviates decreases in photosynthesis under salt stress by enhancing nitrogen and sulfur assimilation and antioxidant metabolism differentially in two mungbean cultivars," Journal of Plant Physiology, vol. 168, no. 8, pp. 807-815, 2011.

[18] N. Iqbal, S. Umar, N. A. Khan, and M. I. R. Khan, "A new perspective of phytohormones in salinity tolerance: regulation of proline metabolism," Environmental and Experimental Botany, vol. 100, pp. 34-42, 2014.

[19] M. Ghorbanli, S. H. Kaveh, and M. F. Sepehr, "Effects of cadmium and gibberellin on growth and photosynthesis of Glycine max," Photosynthetica, vol. 37, no. 4, pp. 627-631, 1999.

[20] M. Ashraf, F. Karim, and E. Rasul, "Interactive effects of gibberellic acid $\left(\mathrm{GA}_{3}\right)$ and salt stress on growth, ion accumulation and photosynthetic capacity of two spring wheat (Triticum aestivum L.) cultivars differing in salt tolerance," Plant Growth Regulation, vol. 36, no. 1, pp. 49-59, 2002.

[21] R. Minocha, R. Majumdar, and S. C. Minocha, "Polyamines and abiotic stress in plants: a complex relationship," Frontiers in Plant Science, vol. 5, article 175, 2014.

[22] S. S. Hussain, M. Ali, M. Ahmad, and K. H. M. Siddique, "Polyamines: natural and engineered abiotic and biotic stress tolerance in plants," Biotechnology Advances, vol. 29, no. 3, pp. 300-311, 2011.

[23] H. Shi and Z. Chan, "Improvement of plant abiotic stress tolerance through modulation of the polyamine pathway," Journal of Integrative Plant Biology, vol. 56, no. 2, pp. 114-121, 2014.

[24] R. Alcázar, J. C. Cuevas, J. Planas et al., "Integration of polyamines in the cold acclimation response," Plant Science, vol. 180, no. 1, pp. 31-38, 2011.

[25] R. Alcázar, J. L. García-Martínez, J. C. Cuevas, A. F. Tiburcio, and T. Altabella, "Overexpression of ADC2 in Arabidopsis induces dwarfism and late-flowering through GA deficiency," Plant Journal, vol. 43, no. 3, pp. 425-436, 2005.

[26] R. Alcázar, F. Marco, J. C. Cuevas et al., "Involvement of polyamines in plant response to abiotic stress," Biotechnology Letters, vol. 28, no. 23, pp. 1867-1876, 2006. 
[27] R. Alcázar, J. Planas, T. Saxena et al., "Putrescine accumulation confers drought tolerance in transgenic Arabidopsis plants overexpressing the homologous Arginine decarboxylase 2 gene," Plant Physiology and Biochemistry, vol. 48, no. 7, pp. 547-552, 2010.

[28] M. Hasanuzzaman, K. Nahar, and M. Fujita, "Plant response to salt stress and role of exogenous protectants to mitigate saltinduced damages," in Ecophysiology and Responses of Plants under Salt Stress, P. Ahmad, M. M. Azooz, and M. N. V. Prasad, Eds., pp. 25-87, Springer, New York, NY, USA, 2013.

[29] P. Rashid, J. L. Karmoker, S. Chakrabortty, and B. C. Sarker, “The effect of salinity on ion accumulation and anatomical attributes in mungbean (Phaseolus radiatus L. cv. BARI-3) seedlings," International Journal of Agriculture and Biology, vol. 6, no. 3, pp. 495-498, 2004.

[30] C. J. Lambridg and I. D. Godwin, "Mungbean," in Genome Mapping and Molecular Breeding in Plants. Volume 3: Pulses, Sugar, and Tuber Crops, C. Kole, Ed., pp. 69-90, Springer, Heidelberg, Germany, 2007.

[31] D. I. Arnon, "Copper enzyme is isolated chloroplasts. Polyphenol oxidase in Beta vulgaris," Plant Physiology, vol. 24, pp. 1-15, 1949.

[32] L. S. Bates, R. P. Waldren, and I. D. Teare, "Rapid determination of free proline for water-stress studies," Plant and Soil, vol. 39, no. 1, pp. 205-207, 1973.

[33] J. Fu and B. Huang, "Involvement of antioxidants and lipid peroxidation in the adaptation of two cool-season grasses to localized drought stress," Environmental and Experimental Botany, vol. 45, no. 2, pp. 105-114, 2001.

[34] R. G. Thurman, H. G. Ley, and R. Scholz, "Hepatic microsomal ethanol oxidation. Hydrogen peroxide formation and the role of catalase," European Journal of Biochemistry, vol. 25, no. 3, pp. 420-430, 1972.

[35] T. Gasper and J. Laccoppe, "The effect of CCC and AMO-1618 on growth, catalase, peroxidase, IAA oxidase activity of young barley seedlings," Physiologia Plantarum, vol. 21, no. 5, pp. 11041109, 1968.

[36] S. Ghosh, J. Saha, and A. K. Biswas, "Interactive influence of arsenate and selenate on growth and nitrogen metabolism in wheat (Triticum aestivum L.) seedlings," Acta Physiologiae Plantarum, vol. 35, no. 6, pp. 1873-1885, 2013.

[37] O. H. Lowry, N. J. Rosebrough, A. L. Farr, and R. J. Randall, "Protein measurement with the Folin phenol reagent," The Journal of Biological Chemistry, vol. 193, no. 1, pp. 265-275, 1951.

[38] W. J. Katembe, I. A. Ungar, and J. P. Mitchell, "Effect of salinity on germination and seedling growth of two Atriplex species (Chenopodiaceae)," Annals of Botany, vol. 82, no. 2, pp. 167-178, 1998.

[39] M. Nabil and A. Coudret, "Effects of sodium chloride on growth, tissue elasticity and solute adjustment in two Acacia nilotica subspecies," Physiologia Plantarum, vol. 93, no. 2, pp. 217-224, 1995.

[40] I. Afzal, S. M. A. Basra, N. Ahmed, and M. Farooq, "Optimization of hormonal priming techniques for alleviation of salinity stress in wheat (Triticum aestivum L.)," Caderno de Pesquisa Serie Biologia, vol. 17, pp. 95-109, 2005.

[41] M. Zaefyzadeh, R. A. Quliyev, S. M. Babayeva, and M. A. Abbasov, "The effect of the interaction between genotypes and drought stress on the superoxide dismutase and chlorophyll content in durum wheat landraces," Turkish Journal of Biology, vol. 33, no. 1, pp. 1-7, 2009.
[42] Q. Chen, M. Zhang, and S. Shen, "Effect of salt on malondialdehyde and antioxidant enzymes in seedling roots of Jerusalem artichoke (Helianthus tuberosus L.)," Acta Physiologiae Plantarum, vol. 33, no. 2, pp. 273-278, 2011. 

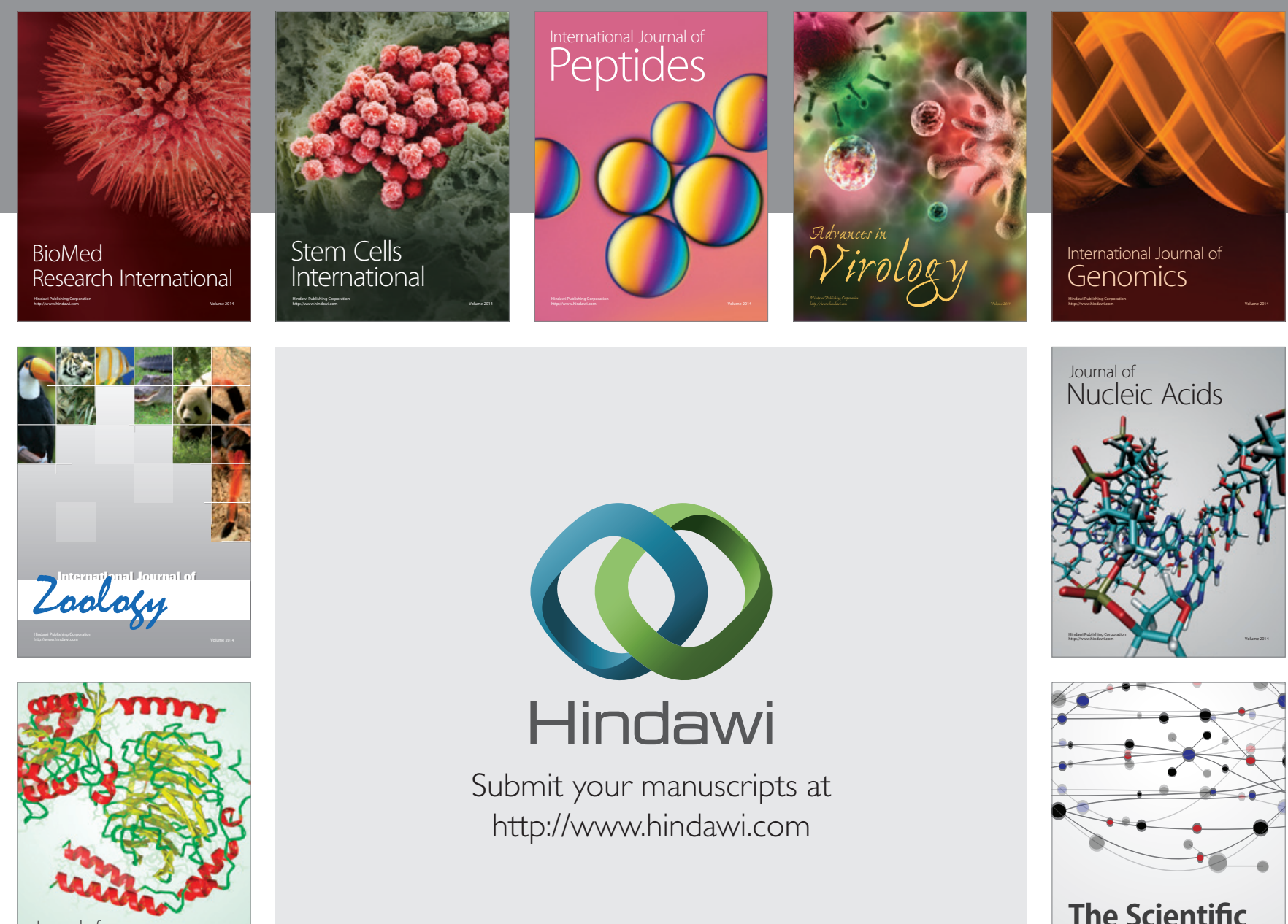

Submit your manuscripts at

http://www.hindawi.com

Journal of
Signal Transduction
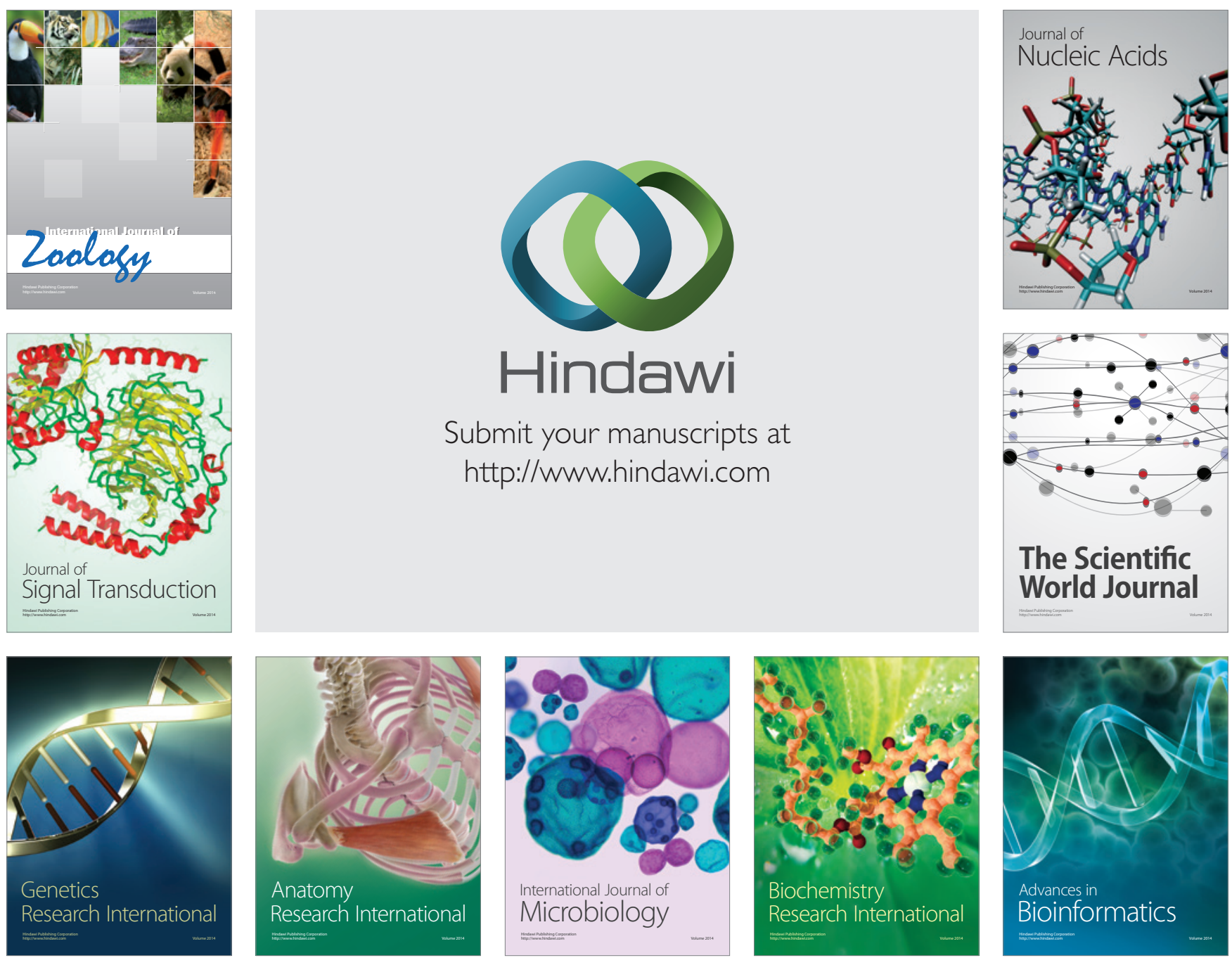

The Scientific World Journal
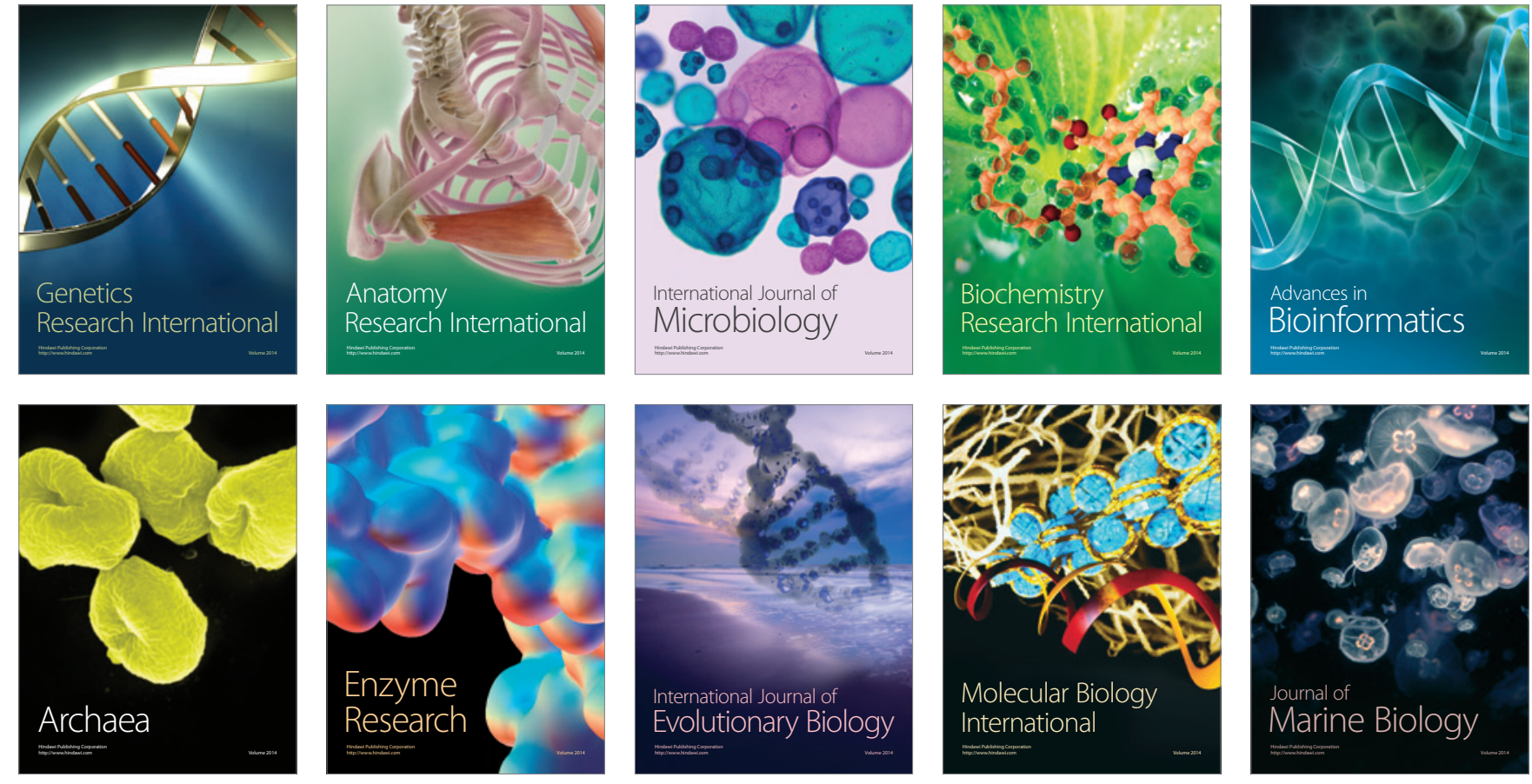